\title{
On the Term "Peak in Darien" Experience
}

\author{
Masayuki Ohkado, Ph.D. \\ Chubu University and University of Virginia
}

\begin{abstract}
In this article, I propose to replace the term a "Peak in Darien" experience, which seems to be recently gaining ground, with some other term. Two reasons for this proposal are: (a) the term, taken from John Keats's wellknown poem "On First Looking into Chapman's Homer," is based on a series of misunderstanding over the years, and (b) using an expression requiring idiosyncratic cultural knowledge irrelevant to the topic may not be the best approach in scientific writing that will be widely read in both Western and non-Western cultures. As a possible substitute, I propose the terms "Encounter with Known Decedent Not Known to Have Died" (EKD) and "Encounter with Unknown Decedent (EUD)" to refer to the relevant cases.
\end{abstract}

KEY WORDS: "Peak in Darien" experience, terminology, Encounter with Known Decedent Not Known to Have Died (EKD) case, Encounter with Unknown Decedent (EUD) case, near-death experience

"Peak in Darien" is a term that authors have used to describe a type of experience near death in which the experiencer encounters a deceased person that the experiencer had no normal way of knowing had died. The term comes from a famous sonnet in which poet John Keats described the excitement he felt when he read a translation of Homer by George Chapman:

Masayuki Ohkado, Ph.D., is a professor on the Faculty of Education at Chubu University in Aichi, Japan. He is currently a visiting professor in the Division of Perceptual Studies at the University of Virginia in Charlottesville, VA. He is grateful to Bruce Greyson, Michael Grosso, Edward Kelly, Lori Derr, and an anonymous reviewer of the Journal for their invaluable comments on an earlier version of this article as well as for the time they spent with him discussing possible alternative terms for "Peak-in-Darien." The terms proposed herein were suggested by Bruce Greyson and Janice Miner Holden. Ohkado also thanks Carlos S. Alvarado for his advice on terminology in the field of parapsychology. Correspondence regarding this article should be sent to Dr. Ohkado at email: ohkado@isc.chubu.ac.jp. 
Much have I travell'd in the realms of gold, And many goodly states and kingdoms seen;

Round many western islands have I been

Which bards in fealty to Apollo hold.

Oft of one wide expanse had I been told

That deep-brow'd Homer rul'd as his demesne;

Yet did I never breathe its pure serene

Till I heard Chapman speak out loud and bold:

Then felt I like some watcher of the skies

When a new planet swims into his ken;

Or like stout Cortez when with eagle eyes

He star'd at the Pacific - and all his men

Look'd at each other with a wild surmise-

Silent, upon a peak in Darien.

John Keats, "On First Looking into Chapman's Homer" (From Forman, 1817, pp. 46-47)

Cases termed "Peak in Darien" are important in the field of neardeath studies because they provide data that most strongly challenge the hypothesis that experiences near death-including near-death experiences (NDEs; Holden, Greyson, \& James, 2009) and nearingdeath awareness (NDA; Kircher, Callanan, and the IANDS Board of Directors, 2011) - are merely subjective hallucinations. Use of the term seems to be prevalent; some recent examples include Grosso (2004); Lester (2005); Kelly, Kelly, Crabtree, Gauld, Grosso, and Greyson (2007, pp. 409-410); Greyson (2010); and Rousseau (2011). In this paper, I trace the origin of this term and propose that because the usage is based on possible misinterpretation, and also because unambiguous clarity is desirable in scientific writing, this term should be shelved, and some other term such as "Encounter with Known Decedent Not Known to Have Died" (EKD) and "Encounter with Unknown Decedent" (EUD), should be adopted.

\section{The Interpretation of the Term "Peak in Darien"}

Bruce Greyson (2010) explained the origin of the term "Peak in Darien," saying that "the poem describes the surprise of the Spaniards, who, upon climbing a peak in Darien (in what is now Panama), expect to see a continent laid out before them, but are faced instead with another ocean" (p. 161). The implied meaning of the metaphor is that the explorers' surprise at encountering the unexpected and amazing sight of the vast Pacific is like an experiencer's surprise at 
encountering the unexpected and amazing sight of a deceased person thought to be still living. This interpretation, however, does not reflect the poet's intention.

As Forman (1817, p. 47) suggested, the relevant part seems to be a reminiscence of William Robertson's The History of America (1817, p. 47). In the story, the Spaniards were expecting, or to be more precise, dying to see the ocean (the South Sea), which their predecessors had all failed to "discover." As Tennyson pointed out, however, Keats confounded Vasco Núñez de Balboa with Hernán Cortés and referred erroneously to the leader of the explorers as "stout Cortez" (Palgrave, 1861, p. 320). In spite of their native guides' words that a journey across the isthmus (of Panama) would take only six days, they had already struggled through woods and mountains under sultry weather and had become exhausted and impatient. In the book, the climax of their exploration, which is of direct relevance to the term of 'Peak in Darien,' is described as follows:

At length the Indians assured them, that from the top of the next mountain they should discover the ocean which was the object of their wishes. When, with infinite toil, they had climbed up the greater part of that steep ascent, Balboa commanded his men to halt, and advanced alone to the summit, that he might be the first who should enjoy a spectacle which he had so long desired. As soon as he beheld the South Sea stretching in endless prospect below him, he fell on his knees, and, lifting up his hands to Heaven, returned thanks to God, who had conducted him to a discovery so beneficial to his country, and so honourable to himself. His followers, observing his transports of joy, rushed forward to join in his wonder, exultation, and gratitude. (Robertson, 1788, pp. 289-290)

As Keats' teacher Charles Cowden Clarke stated, The History of America was one of the surprisingly large collection of books Keats had read (Clarke \& Clarke, 1878), and Keats likened his epiphanic experiences upon reading George Chapman's translation of Homer to the vividly portrayed scene of exultation among the Spanish explorers at the peak in Darien. (Keats also likened his experience to an astronomer who found a new planet). Thus, the Spaniards' reaction was one of relieved exaltation rather than amazed surprise. Consequently, the metaphor breaks down: Unlike the expectant explorers who, after ardent effort and anticipation, finally achieved their goal, the unseeking, unanticipating, unexpecting experiencer first views the unknown-to-be-deceased person with amazed surprise. 


\section{The Origin of the Term in Near-Death Studies}

Both Greyson (2010, p. 161) and David Rousseau (2012, p. 74, note 7) explained that "Peak in Darien" cases came to be so called after the name of a book by Frances Power Cobbe that contained examples of the near-death phenomenon. Greyson (2010) further cited Murphy (1945) as the source of this information. Murphy (1945) also stated that the term is "from the book of this title by Miss Frances P. Cobbe" (p. 8, note 9). Kelly et al. (2007), on the other hand, did not give an account for the origin of the term, although they cited Cobbe's book as one of the sources of such cases (p. 410, note 38).

However, an examination of Cobbe's (1882) own words supports a different conclusion.

That "Peak in Darien," which we must all ascend in our turn, the apex of two worlds, whence the soul may possibly descry the horizonless Pacific of eternity, is the turning-point of human hope. And it appears to me infinitely strange that so little attention has been paid to the cases wherein indications seem to have been given of the perception by the dying of blessed presences revealed to them even as the veil of flesh has dropped away. (p. 6)

Thus, Cobbe herself did not intend to use the term in the sense adopted in the contemporary near-death literature. As her words indicate, with the phrase "Peak in Darien" she intended to mean the threshold between this world and the Hereafter, from which, just as the Spanish explorer descried the long-yearned-for view of the Pacific Ocean, humans are allowed to see the long-yearned-for paradisiacal scenery of the Hereafter.

In accordance with the theme of Cobbe's book, all nine examples she provided in the section entitled "The Peak in Darien: The Riddle of Death" are those in which dying people suddenly expressed wonder, joy, solemn surprise, and awe upon apparently glimpsing the afterlife (Cobbe, 1882, pp. 255-262). The only example she provided that falls in the category of "Peak in Darien Cases" in the modern sense is the following:

Another incident of a very striking character was described as having occurred in a family united very closely by affection. A dying lady, exhibiting the aspect of joyful surprise to which we have so often referred, spoke of seeing, one after another, three of her brothers who had long been dead, and then, apparently, recognized last of all a fourth brother, who was believed by the bystanders to be still living in India. The coupling of his name with that of his dead brothers excited such awe and horror in the mind of one of the persons present that she 
rushed from the room. In due course of time, letters were received announcing the death of the brother in India, which had occurred some time before his dying sister seemed to recognize him. (pp. 261-262)

Although Cobbe (1882, p. 261) used a phrase "incident of a very striking character" to refer to this example, she placed no extra emphasis on the fact that the dying person did not know the death of her fourth brother-and she did not restrict the application of her "Peak in Darien" term to this type of case.

Interestingly, none of the authors before Murphy (1945) cited in Kelly et al. (2007, p. 410, note 38) used the term "Peak in Darien" to refer to these specific types of experiences. Eleanor Sidgwick (1885) referred to such examples as cases "of an apparition of a dead person whose death was unknown to the percipient" (p. 92). Edmund Gurney and Frederic W. H. Myers (1889) did refer to Cobbe's book, but they said only that "Miss Cobbe has collected two or three cases of this type in a little work entitled The Peak of Darien" (p. 459). Alice Johnson (1899, pp. 288-291) and James Hyslop (1908, pp. 88-89) discussed the relevant cases only in descriptive terms, without giving them a particular label. William Barrett (1926) introduced such a case under the heading "Visions seen by the dying of persons by them unknown to be dead" (pp. 6-11).

One article written by Margaret Deland (1927), which Greyson called to my attention, is titled "A Peak in Darien." However, just like Cobbe, the author did not use the term to refer to special cases of the type addressed herein.

As far as I can trace, the origin of the usage goes back to Myers' book Human Personality and Its Survival of Bodily Death, published posthumously in 1903, where it is written as follows:

It is not very uncommon for dying persons to say, or to indicate when beyond speech, that they see spirit friends apparently near them. But, of course, such vision becomes evidential only when the dying person is unaware that the friend whose spirit he sees has actually departed, or is just about to depart, from earth. Such a conjuncture must plainly be rare; it is even rather surprising that these "Peak in Darien" cases, as Miss Cobbe has termed them in a small collection which she made some years ago, should be found at all. (p. 31)

It is interesting to see that Myers, who only referred to Cobbe's book in his 1889 article written with Gurney, came to state in his later book that Cobbe applied the term to those specific cases, which is incorrect. Considering that the book was not complete at the time of the author's death, it might be the case that the error would have been corrected 
prior to publication if the author had lived to finalize the book himself. Although the matter must remain one of speculation, for the present purpose, suffice it to say that use of the term "Peak in Darien" to refer to cases in which those near death see decedents not known to have died is a misinterpretation that goes back at least to 1903 .

\section{Another Reason Against the Use of the Term}

The second argument against the use of the term is simply that it is not advisable to use culturally-entrenched expressions in scientific writing. Because comprehension of the term requires familiarity with the early $19^{\text {th }}$ century English poet John Keats and with American history, it does not seem to be an appropriate term for scientific study.

Many authors who used the term provided some explanation of its origin (Greyson, 2010; Murphy, 1945; Rousseau 2011; Smith, 1954; Smith, 1974; Spraggett, 1974). However, in my view, even if all future authors included such an explanation-which is far from guaranteed-the practice still would not make up for the term's obscurity.

One might argue that, since the term is already in use and recognized by researchers, irrespectively of the original meaning of the term, scholars should keep using it with the meaning already in use. For example, delivering a baby through surgical incisions of the mother's abdomen and uterus is called a "Caesarean section" after Julius Caesar, who erroneously was thought to have been delivered by such an operation; and fever caused by the Plasmodium parasite is called "malaria" after the Italian "mal aria" (bad air) on the mistaken assumption that the disease was caused by air pollution. However, in my view, widespread usage need not justify the perpetuation of inappropriate habits. Just as long-standing sexist terminology has been gradually eliminated from the English language, unnecessarily culturally-loaded expressions should be replaced when feasible with more accurate culturally-neutral ones.

\section{Two Types of Cases}

Based on their "evidential value," Greyson (2004) classified "Peak in Darien" experiences into three types: (a) cases in which the deceased person seen was thought by the experiencer to be alive, (b) cases in which the person seen died immediately before the vision, and (c) cases in which the deceased person seen was unknown to the experiencer.

An example of the first type is a case that Penny Sartori (2008, 
p. 300) reported. One of her hospitalized patients told his family that when he had been in critical condition, he had been visited by his deceased mother and grandmother. To his family's surprise, he added that he had also been visited by his sister, whose death in the previous week had not been told to him for fear of setting back his recovery.

The second type is illustrated by the case of a 9 -year-old child that Brad Steiger and Sherry Steiger (1995:42-46) reported. The child claimed that during his NDE he met his 19-year-old sister. When he opened his eyes and reported his experience at 3:00 in the morning, nobody around him knew that his sister had been killed in an automobile accident just after midnight.

A good illustration of the third type, which has the highest evidential value, is the recent case that neurosurgeon Eben Alexander (2012) reported. In his extremely profound NDE, Alexander met and was guided by a beautiful woman whose identity was unknown to him at the time of experience. Later he found that the woman was his deceased sister, whom he had never met because he had been adopted as a newborn infant.

The first two types share the characteristic that the decedent was known to the experiencer but the decedent's death was unknown to the experiencer at the time of the experience. Therefore, they can be called "Encounter with Known Decedent Not Known to Have Died" (EKD) cases. In Greyson's (2004) classification, the difference between the first two types actually includes two variables. Variable 1: whether or not the experiencer is the only person who is not aware of the death of the person ("yes" in the first type and "no" in the second type) and Variable 2: the time length between the death of the person and the time of the encounter ("long" in the first type and "short" in the second type). These variables yield the following four logical possibilities. (For the sake of argument, I restrict the number of values for the second variable to two.)

Table 1 Four subtypes of encounters with known decedents not known to have died (EKDs)

\begin{tabular}{lllll}
\hline Variable & Subtype 1 & Subtype 2 & Subtype 3 & \multicolumn{1}{c}{ Subtype 4 } \\
\hline $\begin{array}{l}\text { 1: Who is unaware of } \\
\text { decedent's death }\end{array}$ & $\begin{array}{l}\text { Experiencer } \\
\text { only }\end{array}$ & $\begin{array}{l}\text { Experiencer } \\
\text { only }\end{array}$ & $\begin{array}{l}\text { Experiencer } \\
\text { and others }\end{array}$ & $\begin{array}{l}\text { Experiencer } \\
\text { and others }\end{array}$ \\
$\begin{array}{l}\text { 2: Time lapse between } \\
\text { decedent's death and } \\
\text { encounter }\end{array}$ & Long & Short & Long & Short \\
\hline
\end{tabular}


Further variables could be added to indicate the evidential value of a case-for instance, the presence or absence of other people at the time of experience and its report. However, I believe that incorporating these variables unnecessarily complicates the classification and that Greyson's Type 1 and Type 2 (including their possible subtypes) should be grouped together as "Encounter with Known Decedent Not Known to Have Died" (EKD) cases. The third type, in which the person whose identity was not known at the time of the experience, can be called "Encounter with Unknown Decedent" (EUD) cases.

\section{Conclusion}

The word hound (Old English hund), which originally meant 'a dog in general,' has come to mean 'a special type of dog developed for hunting other animals.' Likewise, meat (Old English met), which originally meant 'food in general,' has come to be restricted in use to a special type of food. Such semantic 'narrowing' is a widely acknowledged linguistic evolutionary process-one that the term "Peak in Darien" has also undergone, first meaning death-bed vision in general and later restricted to a special type of experience near death. In this respect, perhaps, the semantic change in this term is understandable. However, the point remains that using a term the comprehension of which requires idiosyncratic cultural knowledge irrelevant to the topic is not desirable in scientific writing. Therefore, as a possible alternative, I propose the more explicit terms "Encounter with Known Decedent Not Known to Have Died" (EKD) and "Encounter with Unknown Decedent" (EUD).

\section{References}

Alexander, E. (2012). Proof of heaven: A neurosurgeon's journey into the afterlife. New York, NY: Simon \& Schuster.

Barrett, W. F. (1926). Death-bed visions. London, England: Methuen.

Clarke, C., \& Clarke, M. (1878). Recollections of writers. New York, NY: Charles Scribner's Sons.

Cobbe, F. P. (1877). The peak in Darien: The riddle of death. Little's Living Age (5th series), 19, 374-379.

Cobbe, F. P. (1882). The peak in Darien, with some other inquiries touching concern of the soul and the body. Boston, MA: George H. Ellis.

Deland, M. (1927). A peak in Darien: The case for and against psychical belief. In C. Murchison (Ed.), The case for and against psychical belief (pp. 121-146). Oxford, England: Clark University Press. 
Forman, B. (1817). The complete works of John Keats (Vol. 1). New York, NY: Thomas Y. Crowell.

Greyson, B. (2010). Seeing dead people not known to have died: "Peak in Darien" experiences. Anthropology and Humanism, 35(2), 159-171.

Grosso, M. (2004). Experiencing the next world now. New York, NY: Paraview Books.

Gurney, E., \& Myers, F. W. H. (1988). On apparitions occurring soon after death. Proceedings of the Society for Psychical Research, 5, 403-485.

Holden, J. M., Greyson, B., \& James, D. (Eds.). (2009). The handbook of neardeath experiences: Thirty years of investigation. Santa Barbara, CA: Praeger/ ABC-CLIO.

Hyslop, J. H. (1908). Psychical research and the resurrection. Boston, MA: Small, Maynard.

Johnson, A. (1899). Coincidences. Proceedings of the Society for Psychical Research, 14, 158-330.

Kelly, E., Kelly, E. W., Crabtree, A., Gauld, A., Grosso, M., and Greyson, B. (2007). Irreducible mind: Toward a psychology for the 21st century. Lanham, MD: Rowman \& Littlefield.

Kircher, P. M., Callanan, M., \& the IANDS Board of Directors. (2011). Near-death experiences and nearing death awareness in the terminally ill. Retrieved from http://iands.org/about-ndes/nde-and-the-terminally-ill.html

Lester, D. (2005). Is there life after death? An examination of the empirical evidence. Jefferson, NC: McFarland.

Murphy, G. (1945). An outline of survival evidence. Journal of the American Society for Psychical Research, 39(1), 2-34.

Myers, F. W. H. (1903). Human personality and its survival of bodily death (2 vols.). London, England: Longmans, Green.

Palgrave, F. T. (1861). The golden treasury of the best songs and lyrical poems in the English language. London, England: Macmillan.

Robertson, W. (1788). The history of America (Vol. 1, 5th ed.). London, England: A. Strahan; T. Cadell, in the Strand; and J. Balfour, at Edinburgh.

Rousseau, D. (2012). The implications of near-death experiences for research into the survival of consciousness. Journal of Scientific Exploration, 26(1), 43-80.

Sartori, P. (2008). The near-death experiences of hospitalized intensive care patients: A five year clinical study. Lewiston, Scotland: Edwin Mellen.

Sidgwick, E. M. (1885). Notes on the evidence, collected by the Society, for phantasms of the dead. Proceedings of the Society for Psychical Research, 3, 69-150.

Smith, A. (1954). Immortality: The scientific evidence. New York, NY: PrenticeHall.

Smith, S. (1974). Life is forever: Evidence for survival after death. New York, NY: Putnam.

Spraggett, A. (1974). The case for immortality: The study of life after death. New York, NY: New American Library.

Steiger, B., \& Steiger, S. H. (1995). Children of the light: The startling and inspiring truth about children's near-death experiences and how they illuminate the beyond. New York, NY: Signet-Penguin. 